\title{
ANALISIS CURRENT RATIO (CR), DEBT TO EQUITY RATIO (DER), TOTAL ASSET TURNOVER (TATO) DAN PENGARUHNYA TERHADAP GROSS PROFIT SERTA DAMPAKNYA PADA NILAI PERUSAHAAN
}

(Studi Kasus Perusahaan Sub Sektor Kimia)

\section{Hendri Gunawan}

Dosen Pengajar Fakultas Ekonomi Universitas Pamulang Email: hendrigunawan25@gmail.com

\begin{abstract}
ABSTRAK
Tujuan dilakukan penelitian ini adalah menganalisis pengaruh Current Ratio (CR), Debt to Equity Ratio (DER), Total Assest Turnover (TATO) dan pengaruhnya terhadap Gross Profit serta dampaknya pada Nilai Perusahaan baik secara parsial maupun secara simultan. Populasi dalam penelitian ini adalah seluruh Perusahaan Sub Sektor Kimia yang terdaftar di BEI sebanyak 11 perusahaan. Dan setelah dilakukan seleksi ( purposive sampling ), sampel yang dipakai adalah 5 perusahaan Sub Sektor kimia di BEI untuk rentang waktu tahun 2011 - 2016. Metode penentuan sampel yang dipakai adalah metode purposive sampling dan uji statistik, yaitu uji regresi data panel model random effectyang akan digunakan dalam penelitian ini..

Metode penelitian yang dipakai adalah deskriptif kuantitatif dengan melakukan kegiatan pengumpulan dokumen dari sekunder laporan keuangan perusahaan. Model penelitian yang dipakai adalah regresi data panel dengan melakukan Uji Chow dan Haussman. Untuk uji asumsi klasik menggunakan Uji Normalitas, Multiklonieritas, Heteroskedastisitas dan Uji Autokorelasi.

Hasil penelitian secara parsial menunjukan bahwa: 1)CR berpengaruh signifikan terhadap Gross Profit.(prob) t hitung $(0.0000)<0,05$. 2) DER berpengaruh signifikan terhadap Gross Profit.(prob) t hitung $(0.0000)<0,05.3)$ TATO berpengaruh signifikan terhadap Gross Profit.(prob) t hitung $(0.0000)<0,05$. 4) Gross Profit berpengaruh signifikan terhadap PER perusahaan. (prob) t hitung $(0.0000)<0,05$. 5) CR, DER, TATO secara simultan berpengaruh signifikan terhadap Gross Profit perusahaan.(prob) f hitung $(0.0000)<0,05$. HasilAdjusted $R$ Squareadalah 0.9960. Hal ini menunjukan persentase pengaruh variabel independen terhadap variabel dependen sebesar $99.60 \%$, sedangkan $00.40 \%$ dipengaruhi faktor lain. Dengan demikian memiliki hubungan yang sangat kuat.
\end{abstract}

Kata kunci : Current Ratio(CR), Debt to Equity Ratio (DER), Total Asset Turnover (TATO), Gross Profit dan Price Earning Ratio(PER)

\section{ABSTRACT}

This study aims to analyze the influence of Current Ratio (CR), Debt to Equity Ratio (DER), Total Asset Turnover (TATO) and its effect on Gross Profit and its impact on Corporate Value either partially or simultaneously. Population in this research is all Sub 
Sector of Chemical Company listed on BEI as many as 11 companies. And after the selection (purposive sampling), the sample used is 5 companies Sub Sector of chemicals listed on the BEI period 2011 to 2016. The method of determining the sample used is the method of purposive sampling and statistical test using regression test panel data random model Effect.

The research method used is descriptive quantitative by doing document collection activity from secondary to company financial report. The research model used is panel data regression by doing Chow and Haussman Test. For the classical assumption test using Normality Test, Multiclonerity, Heteroscedasticity and Autocorrelation Test.

The result of this research shows that: 1) CR has significant effect to Gross Profit. (Prob) $t$ arithmetic (0.0000) <0.05. 2) DER has significant effect to Gross Profit. (Prob) $t$ arithmetic $(0.0000)<0.05$. 3) TATO has significant effect to Gross Profit. (Prob) $t$ arithmetic (0.0000) <0.05.4) Gross Profit has significant effect to PER company. (Prob) $t$ arithmetic (0.0000) <0.05. 5) CR, DER, TATO simultaneously have a significant effect on the company's Gross Profit. (Prob) f arithmetic (0.0000) <0.05. Adjusted $R$ Square result is 0.9960. This shows the percentage of independent variable influence to the dependent variable of $99.60 \%$, while $00.40 \%$ influenced by other factors. Thus has a very strong relationship.

\section{Keywords: CurrentRatio (CR),Debt to Equity Ratio (DER), Total} AssetTurnover(TATO),GrossProfit and PriceEarning Ratio (PER).

1. PENDAHULUAN

\section{A. Latar Belakang}

Dunia usaha merupakan peluar yang bisa meningkatkan kesejahtera: hidup.Baik untuk pelaku usaha i sendiri, maupun para pekerja.Ds kegiatan usaha tersebut dap meningkatkan pesatnya la perekonomian dan meningkatn: permintaan barang-barang ha: produksi kimia. Terutama untı perusahaan yang aplikasi pekerjaan di kebutuhan proses produksin: mengandalkan bahan kimia.

Menurut Handayani (2008: 10C informasi keuangan adalah "Das penilaian harga (return) saham, keputusan untuk membeli atau menjual saham".

Banyaknya beberapa masalah yang terjadi diperusahan Sub Sektor Kimia, menjadikan kinerja, profit dan juga nilai perusahaan Sub Sektor kimia semakin menurun. Dan berikut ini penulis jabarkan mengenai beberapa masalah yang terjadi diperusahaan Sub Sektor Kimia dari beberapa sumber yang dapat menghambat pertumbuhan dan juga daya saing perusahaan.

Dari Kementrian Perindustrian mengatakan bahwa impor bahan 
baku jakarta sampai dengan semester 1 tahun ini, untuk impor bahan baku dan penolong mengalami kenaikan $7,48 \%$ diakhir tahun 2016. Hal ini diakibatnya belum mampunya supply dalam negeri untuk menghasilkan beberapa jenis kebutuhan bahan baku dan juga bahan penolong. (www.kemenperindo.go.id/artikel/4 146/Impor-Bahan-Baku-TerusMeningkat).

Current Ratio ( CR ) digunakan untuk mengukur kemampuan perusahaan didalam memenuhi semua kewajiban yang dimiliki oleh perusahaan. Semakin rendah nilai CR, maka akan mengindika ketidak mampuan perusahac didalam memenuhi utang jangl pendek.

Debt Ratio ( DR ) merupakan ras hitung yang dapat mengukur terke keefektifan utang yar dibandingkan terhadap total as yang dalam sebuah kegiatan prosi usaha. Hal ini bisa dikaitkan seca sistematis bahwa tingginya utar untuk kegiatan modal usaha, bun pinjaman yang dibayar ak: semakin besar pula. Hal ini tentun! akan berpengaruh didalam pendapatan bersih suatu perusahaan didalam hasil penjualannya. Sama halnya dengan Debt to Equity Ratio ( DER ) merupakan rasio perbandingan utang terhadap ekuitas perusahaan. Atau bisa diartikan sebagai kondisi yang menunjukan kemampuan perusahaan untuk memenuhi kegiatan operasionalnya dengan menggunakan modal sendiri. Artinya, dengan banyaknya modal kerja suatu perusahaan akan dapat memperkecil melakukan pinjaman, sehingga dapat meminimalkan pembayaran bunga dari suatu pinjaman.

Total AssetTurnover(TATO) bisa dijadikan alat pengukuran efektivitas dan efisiensi pemanfaatan total asset suatu perusahaan didalam mendapatkan keuntungan. Dengan tingginya TATO perusahaan, tingkat produktivitasnya semakin baik.Dan tentunya profit yang diterima perushaan akan semakin baik pula. Namun sebaliknya, bila perusahaan tidak mampu mengelola total asset yang dimilikinya secara efektif dan efisien, maka tingkat profitabilitas 
yang didapat oleh perusahaan aki semakin kecil pula.

Menurut Kasmir ( $2011: 303$ ), lat kotor (gross profit) adalah"lat yang diperoleh sebelum dikuran biaya-biaya yang menjadi bebc perusahaan. Artinya lat keseluruhan yang pertama sek $\varepsilon$ perusahaan peroleh. Sedangkan lat bersih (netprofit) merupakan lat yang telah dikurangi biaya-bia! yang merupakan beban perusahac dalam suatu periode terten termasuk pajak".

Current Ratio (CR), Debt ToEqui Ratio (DER), Total Asset Turnov, (TATO),Debt Ratio (DR), Gro Profit, pertumbuhan penjualan, $\mathrm{d} c$ ukuran suatu perusahaan merupaki faktor-faktor yang dap mempengaruhi profitabilitas sua perusahaan.

Price Earning Ratio ( PER ) merupakan salah satu komponen penting yang harus dipertimbangkan didalam menganalisa keberhasilan perusahaan. Price Earning Ratio (PER) merupakan ukuran nilai dari suatu penilaian harga saham dalam sebuah perusahaan. Dalam hal ini tentunya sangat menjadi pertimbangan tersendiri bagi para investor sebelum menanamkan modal kerja.

Menurut Simamora (2000 : 531), PER adalah"suatu rasio yang lazim dipakai untuk mengukur harga pasar (market price) setiap lembar saham biasa dengan laba per lembar saham".

Dengan demikian pengaruh Current Ratio ( CR ), Debt to Equity Ratio ( DER ), Total Asset Turnover ( TATO ) terhadap Gross Profit serta dampaknya pada Nilai Perusahaan ( PER ) akan dilakukan penelitian dan analisa.

Berikut ini adalah data CR, DER, TATO, Gross Profit danPER dari perusahaan Sektor Industri Dasar dan Kimia, Sub Sektor Kimia yang terdaftar di BEI.

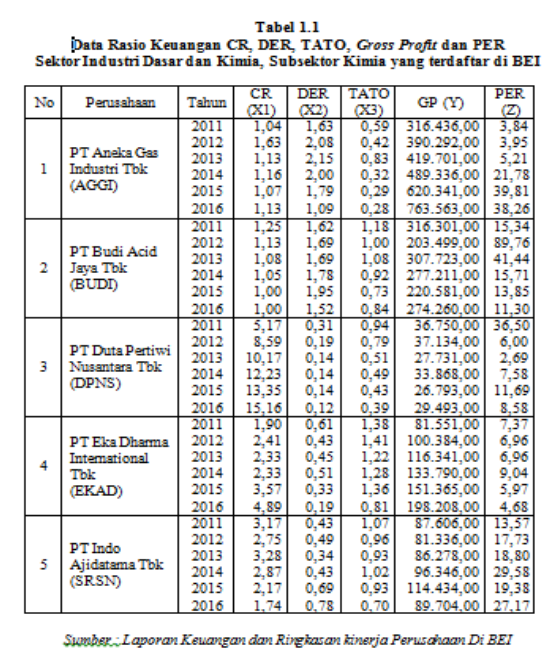


Dari hasil uraian, dapat kita simpulkan bahwa untuk nilai $\mathrm{CR}$, DER, TATO, Gross Profit dan PER perusahaan Sub Sektor kimia ada yang mengalami fluktuatif/ketidak stabilan data setiap tahunnya.

Dari hasil data diatas, maka sangat menarik bila peneliti melakukan penelitian tentang CR, DER, TATO, Grsoss Profit dan PER.

\section{B. Perumusan Masalah}

1. Bagaimana menilai kinerja keuangan perusahaan dari CR, DER, TATO dan Gross Profit?

2. Bagaimana nilai perusahaan dinilai dari Price Earning Ratio( PER )?

3. BagaimanaCR,

DERdanTATOsecara parsial dapat mempengaruhiGross Profit?

4. BagaimanaCR,DER dan TATO,secara simultanmempengaruhiGrossProfit?

5. Bagaiaman dampak Gross Profit terhadap nilai perusahaan ( PER )?

C. Tujuan Penelitian

1. Mengetahui kinerja keuangan perusahaan Sub Sektor Kimia dinilai dari CR, DER, TATO dan Gross Profit.

2. Untuk mengetahui nilai perusahaan dinilai dari PER pada periode tahun 2011-2016.
3. Untuk mengetahui CR, DER dan TATO secara parsial berpengaruh terhadap Gross Profit.

4. Untuk mengetahuiCR,DER danTATO secarasimultan berpengaruh terhadapGross Profit.

5. Untuk mengetahui dampak Gross Profit terhadap nilai perusahaan ( PER ).

\section{Tinjauan Pustaka}

A. Pengertian Manajemen

\section{Keuangan}

Menurut pengertian secara umum, manajemen keuangan adalah aktivitas perusahaan yang berhubungan dengan bagaimana memperoleh dana, menggunakan dana, dan mengelola asset sesuai dengan tujuan perusahaan secara menyeluruh. Manajemen keuangan adalah suatu kegiatan perencanaan, penganggaran, pemeriksaan, pengelolaan, pengendalian, pencarian, dan penyimpanan dana yang dimiliki oleh perusahaan.

Dari hasil pernyataan Sutrisno (2003:3) yang dimaksud dengan manajemen keuangan adalah "sebagai suatu aktifitas perusahaan yang berhubungan dengan usaha-usaha mendapatkan dana perusahaan dengan biaya yang murah serta untuk 
menggunakan dan mengalokasik:

dana tersebut secara efisien”.

Menurut Agus Sartono (2001:6)

yang dimaksud dengan manajems

keuangan adalah"manajemen dan

Baik yang berkaitan deng; pengalokasian dana dalam berbag bentuk investasi secara aktif maupı usaha pengumpulan dana untuk bia: investasi atau pembelanjaan seca efisien".

Menurut Bambang Riyanto (2001: 4) manajemen keuangan adali "keseluruhan aktivitas yar bersangkutan dengan usaha unt mendapatkan dana dan menggunaki atau mengalokasikan dana tersebut".

\section{B. Fungsi Manajemen Keuangan}

Manajemen keuangan dap meningkatkan efektifitas dan efisien perusahaan didalam menghasilkan lal perusahaan.

Menurut Martono dan Agus ( 201' 4 ), "ada tiga fungsi utama dala manajemen keuangan, yaitu":

1) Pengambilan Diputuskann! Penanaman Modal

Dalam pengambilc diputuskannyainvestasi mencakup bagaimana mengestimasi aliran kas yang dihasilkan dari suatu investasi dan bagaimana mengevaluasi aliran kas tersebut sehingga bisa diperoleh kesimpulan apakah investasi tersebut layak dilakukan atau tidak.

2) Pengambilan Keputusan Pendanaan Pengambilan keputusan melakukan pendanaan bisa berasal dari dalam maupunluar perusahaan. Dalam hal ini peran manajer keuangan untuk memenuhi pendanaan perusahaanakan semakin komplek dalam persaingan pasar global.

3) Pembagian Deviden

Dalam pembagian deviden ini sering terjadi konflik antara pemilik saham dengan manajer.Manajer biasanya lebih senang menggunakan hasil keuntungan usaha untuk pengadaan asset dan kemajuan perusahaan daripada harus membagi deviden kepada para pemilik saham.Sedangkan pemilik saham selalu menginginkan agar hasil usaha dapat langsung dibagi dalam bentuk deviden.Hal inilah yang sering mengakibatkan terjadinya konflik keagenan antara manajer dengan pemilik saham.

\section{Tujuan Manajemen Keuangan}

Menurut Mulyadi (2006: 10) tujuan manajemen keuangan adalah "mencerminkan dari kegiatan seharihari yang dilakukan oleh manajemen 
keuangan. Dalam hal ini kegiatan keuangan terbatas pada kegiatan terhadap pengelolaan keuangan perusahaan yang meliputi perencanaan sumber keuangan (pembelanjaan), perencanaan alokasi keuangan (investasi), keuangan dan modal perusahaan".

D.

$$
\text { Pengertian }
$$

Laporan

\section{Keuangan}

Menurut Kasmir (2005:

laporan keuangan adali "penggambaran pos-pos keuang: perusahaan yang diperoleh dalam sua periode".

Menurut Sofyan Syafri Harahi (2009:105) laporan keuangan adal: "suatu laporan keuangan yar menggambarkan kondisi keuangan d: hasil usaha suatu perusahaan pada sa tertentu atau jangka waktu tertentu".

E.

\section{Tujuan Laporan Keuangan}

Dalam sebuah perusahaa laporan keuangan sangat diperluk: sebagai bahan evaluasi $\mathrm{d}_{i}$ pengambilan keputusan organisasi.Ol, karena itu, laporan keuangan har dibuat secara akurat dan actu menggambarkankondisi perusaha: yang sebenarnya.Disinilah sang diperlukan peran serta, kontrol di pengecekan secara langsung ols manajer keuangan.
Menurut Djarwanto (2001: 7) "Laporan Keuangan disusun dengan maksud menyediakan laporan kemajuan perusahaan secara periodik. Manajemen perlu mengetahui bagaimana perkembangan keadaan investasi dan dalam perushaan dan hasi-hasil yang dicapai selama jangka waktu yang diamati".

\section{F. Analisis Laporan Keuangan}

Untuk mengetahui kinerja suatu perusahaan, maka diperlukan suatu analisis dari laporan keuangan. Dari hasil analisis inilah kemudian kita dapat mengetahui nilai perusahaan, kondisi keuangan suatu perusahaan, dan juga dapat mengambil keputusan tentang investasi yang akan kita ambil untuk memilih perusahaan mana yang paling tepat untuk dapat melakukan kegiatan investasi.

Menurut Munawir (2002: 36), “analisis laporan keuangan digunakan untuk menyederhanakan data sehingga dapat bih dimengerti atau lebih berarti:.

Berikut ini beberapa analisis rasio yang bisa digunakan sebagai alat menilai kinerja perusahaan.

\section{Current Ratio (CR)}


Rasio ini dapat digunakan sebagai alat untuk mengukur kemampuan perusahaan membayar utang jangka pendeknya melalui aktiva lanc yang dimiliki oleh suatu perusahaa Semakin tinggi nilai hasil rasiony tentu akan semakin lebih baik.

Dibawah ini adal formula bagaimana menghitung Current Ratiosuatu perusahaan:

Current Ratio $=\frac{\text { Current Assets }}{\text { Current Liabilities }}$

\section{Rasio Perputaran Total Aktir} (Total Assets Turnover)

Rasio ini dapat digunakan sebag alat untuk mengukur keefektif; perusahaan untuk memaksimalki seluruh aktiva yang dimiliki untuk menghasilkan tingkat penjualan yang tinggi. Semakin besar nilai TATO, akan semakin lebih baik.

Untuk menghitung nilai TAT $^{n}$ suatu perusahaan, kita bi menggunakan rumus dibawah:

Total Assets Tumover $=\frac{\text { Penjualan }}{\text { Total Aktiva }}$

\section{Debt to Equity Ratio (DER)}

Rasio ini digunakan untuk menil utang dengan ekuitas.Rasio i dicari dengan membandingkan seluruh utang dengan seluruh ekuitas yang ada.

Untuk mencari rasio ini, kita dapat menggunakan rumus sebagai berikut:

Debt to Asset Ratio $=\frac{\text { Total Debt }}{\text { Total Assets }}$

\section{Gross Profit}

Laba Kotor (Gross Profit) adalah tingkat keuntungan suatu perusahaan dari hasil penjualan sebelum dikurangi dengan seluruh biaya produksinya.

Untuk menghitung Laba Kotor ( Gross Profit ) dapat menggunakan rumus dibawah ini:

Gross Profit $(G P)=$ Net Sales - HPP

\section{Analisis Price Earning Ratio}

\section{PER )}

Sudana (2011: 23), ( PER ) adalah "rasio yang mengukur tentang bagaimana investor menilai prospek pertumbuhan perusahaan dimasa yang akan datang dan tercermin pada harga saham yang bersedia dibayar oleh investor untuk setiap rupiah laba yang diperoleh perusahaan". 
Menurut Irham Fahmi (2012: 138),

Price Eraning Ratio( PER )

adalah"perbandingan Market Price

Share (harga pasar per lembar saham) dengan Earning Pershare (laba per lembar saham)".

$$
\begin{aligned}
& \text { PER }=\frac{P S}{E P S} \\
& \text { Keterangan: } \\
& \text { Ps : Price stock } \\
& \text { EPS : Eaming Per Share }
\end{aligned}
$$

\section{G. Hipotesis Penelitian}

1. Pengaruh Curent Ratio ( $\mathrm{CR}$ ) Terhadap Gross Profit:

Ho1: CR tidak berpengaruh signifikan terhadap Gross Profit

Ha1: CR berpengaruh signi1 terhadap Gross Profit

2. Pengaruh DER Terhadap Gro Profit

Ho2 : DER tidak berpengarl signifikan terhadap Gross Profit

Ha2 : DER berpengaruh signifikء terhadap Gross Profit

3. Pengaruh TATO Terhadap Gro Profit

Ho3 : TATO tidak berpengar signifikan terhadap Gross Profit

Ha3 : TATO berpengaruh signifik: terhadap Gross Profit
4. Pengaruh Gross Profit Terhadap PER Perusahaan

Ho4 : Gross Profit tidak berpengaruh signifikan terhadap PER

Ha4 : Gross Profit berpengaruh signifikan terhadap PER

5. Pengaruh CR, DER, TATO Secara Simultan Terhadap Gross Profit

Ho5 : CR, DER, TATO secara simultan tidak berpengaruh signifikan terhadap Gross Profit perusahaan

Ha5 : CR, DER, TATO secara simultan berpengaruh signifikan terhadap Gross Profit perusahaan METODE PENELITIAN

Penelitian dilakukan dirumah peneliti sendiri, dikampus Universitas Pamulang dan juga melakukan searching di internet Metode penelitian yang digunakan adalah"Deskriptif kuantitatif, dimana metode tersebut dibagi dalam metode deskriptif dan metode kuantitatif sehingga dengan menggambarkan pembahasan yang lebih banyak berhubungan dengan rumus yang bersumber dari laporan keuangan". 
Populasi didalam penelitian i adalah seluruh perusahaan $\mathrm{St}$ Sektor Kimia yang terdaftar di BI sebanyak 11 perusahaan.

Sampel penelitian dari 1 perusahaan tersebut lalu dise IV. lagi berdasarkanpurpose saml judgement, yakni merupakan pemilihan sampel dengan didasarkan beberapa tahapan deng: kriteria tertentu.

Menurut Sugiyono (2014: 207 metode statistic deskriptif adali "statistik yang digunakan unt menganalisis data dengan ca mendeskripsikan at: menggambarkan data yang teli terkumpul sebagaimana adanya tanpa bermaksud membu kesimpulan yang berlaku untt umum atau generalisasi".

Program yang dipakai unt menunjang keberhasilan penelitic adalah dengan menggunakan i Views 7.Data yang digunakan dala penelitian ini adalah data panel $d \dot{c}$ juga untuk n hanya berjumlah 30 .

Metode yang digunakan adalı survey lapangan dengs menggunakan metode penelitic kuantitatif. Survey ini menjelaski analisis pengaruh $\mathrm{CR}$, DER dan TATO terhadap Gross Profit serta dampaknya pada PER Perusahaan pada perusahaan Sub Sektor Kimia yang terdaftar di BEI.

HASIL PENELITIAN DAN PEMBAHASAN

\section{A. Gambaran Umum Objek}

\section{Penelitian}

Menurut Kuncoro (2207: 167), industri dalam arti sempit adalah "kumpulan perusahaan yang menghasilkan produk sejenis dimana terdapat kesamaan dalam bahan baku yang digunakan, proses, produk akhir dan konsumen akhir".

\section{Hasil Penelitian}

\section{Uji Statistik Deskriptif}

Analisa deskriptif dilakukan terhadap data sampel yang ada, baik terhadap variabel independen maupun variable dependen yang akan dilakukan dengan alat analisis E-views 7. Sehingga didapatkan nilai rata-rata, median, maksimum, minimum, standar deviasi, skewness, kurtosis dan lainnya. Analisis deskriptif ini juga akan dilakukan terhadap rata-rata pengaruh $\mathrm{CR}$, DER dan TATO terhadap Gross Profit dan juga 
Gross Profit terhadap Nilai perusahaan yang diukur dengan PER.

\section{Uji Chow}

Uji dilakukan untuk melakukan pemilihan apakah data yang akan diolah lebih baik menggunakan analisis regresi linear biasa ( Common atau Poled ) atau menggunakan analisis data panel ( Fixed Effect Model ). Melalui probability yang diperoleh dari hasil Uji Chow dengan melakukan pengujian test redundantfixed effect dapat dilakukan pemilihan analisis data yang sesuai.

Hipotesis yang penulis lakukan adalah sebagai berikut:

$\mathrm{H} 0$ : Model Common Effect

H1 : Model Fixed Effect

Keterangan : diterima dan menggunakan analisis regresi linear biasa ( common pooled).

H1 : Jika $\mathrm{p}<0,05 \rightarrow$ Maka $\mathrm{F}$ ditolak dan digunakan analisis da panel ( fixed effect model).

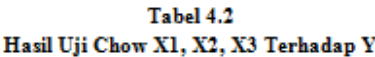

\begin{tabular}{|c|c|c|c|c|}
\hline Enects Test & & Statstc & df. & Proo. \\
\hline $\begin{array}{l}\text { Cross-6ection F } \\
\text { Cross-bection CN1-square }\end{array}$ & & $\begin{array}{r}-0.0000000 \\
0.000000\end{array}$ & $(4,22)_{4}$ & $\begin{array}{l}1.0000 \\
1.0000\end{array}$ \\
\hline \multicolumn{5}{|c|}{ 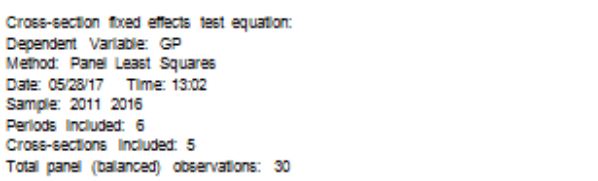 } \\
\hline Varlable & Coeftclemt & sta. Error & i-statstc & Prob. \\
\hline $\begin{array}{c}C \\
\text { CR } \\
\text { DER } \\
\text { TATO }\end{array}$ & $\begin{array}{r}15.483356 \\
-0.794002 \\
-0.355555 \\
-2.418003\end{array}$ & $\begin{array}{l}0.114730 \\
0.101119 \\
0.009996 \\
0.037205\end{array}$ & $\begin{array}{r}1349549 \\
-7.755123 \\
-3393584 \\
-65.00056\end{array}$ & $\begin{array}{l}0.0000 \\
0.0000 \\
0.0000 \\
0.0000\end{array}$ \\
\hline $\begin{array}{l}\text { R-6quared } \\
\text { Adusted R-6quared } \\
\text { S.E. of regression } \\
\text { Sum squared resid } \\
\text { Log Irealinood } \\
\text { F-6tatstic } \\
\text { Prob(F-6tatstic) }\end{array}$ & $\begin{array}{l}0.995979 \\
0.995531 \\
0.017313 \\
0.007793 \\
81.26701 \\
2050.585 \\
0.000000\end{array}$ & 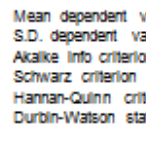 & $\begin{array}{l}\text { var } \\
\text { var } \\
\text { von } \\
\text { ther. } \\
\text { tat }\end{array}$ & $\begin{array}{r}13.07257 \\
0.298279 \\
-5.151134 \\
-4.954308 \\
-5.091957 \\
2.755452\end{array}$ \\
\hline
\end{tabular}

Tabel 4.3

Hasil Uji Chow Variabel Y Terhadap Z Redundamt Fixed Enects Tests Equation: Unttited Test cross-6ection fxed entects

\begin{tabular}{lcrc}
\hline \hline Entects Test & Statstic & dt. & Prob. \\
\hline \hline Cross-section F & -0.0000000 & $(4,24)$ & 1.0000 \\
Cross-section Cnl-square & 0.000000 & 4 & 1.0000 \\
\hline \hline
\end{tabular}

Cross-section txed eftects test equation: Dependent Variable: PER Method: Panel Least Squares Sample: 20112016 cross-sectlons included: Total panel (balances) observatons: 30

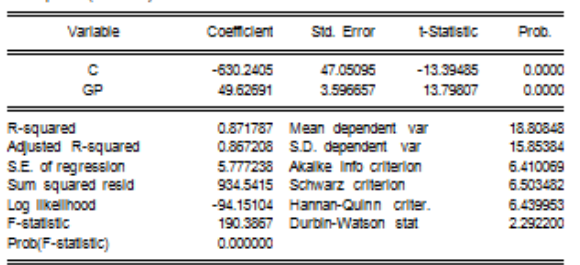

Dari keterangan tabel diatas, didapatkan nilai probability cross section sebesar $1.0000>0.05$. Maka H0 diterima dan menggunakan analisis model regresi linear biasa ( common / pooled ).

\section{Uji Haussman}


Pada Uji Haussman dilakukan untı memilih model penelitian yanc akan digunakan pada analisa regre data panel, apakah lebih sesu menggunakan fixed effect atc random effect model.

Hipotesis yang digunakan untı pengujian dengan menggunakan $L$ Haussman adalah sebagai berikut:

H0 : Model Random Effect

H1

Keterangan :

H0 : Jika $\mathrm{p}>0,05$, maka $\mathrm{F}$ diterima dan menggunakan Rando Effect Model

: Jika $\mathrm{p}<0,05$, maka H0 ditols dan menggunakan Fixed Effe Model

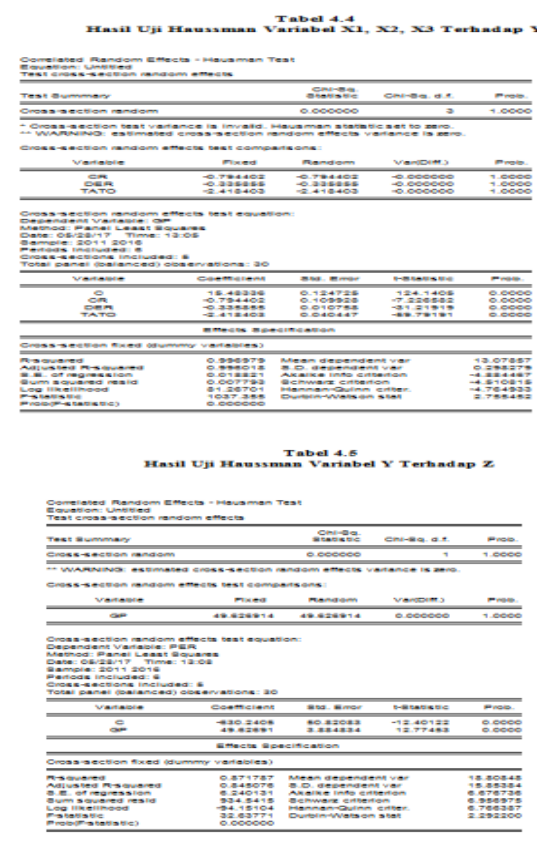

Dari tabel diatas, yang merupakan Uji Haussman, dapat disimpulkan untukprobabilitas yang dihasilkan dengan hasil nilai cross section adalah $1.0000>0,05$. Dengan demikian $\mathrm{H} 0$ diterima dan $\mathrm{H} 1$ ditolak, dan dengan tingkat signifikansi $5 \%$ lebih efektif menggunakan pendekatan Random Effect Model.

\section{Uji Normalitas}

Menurut Ghozali ( 2013 : 160 ), "uji ini dilakukan dengan maksud untuk menguji apakah residual data atau variabel pengganggu memiliki distribusi secara normal atau tidak. Berikut hasil Uji Normalitas yang bertujuan untuk mengetahui dalam model variable independen dan dependen berdistribusi normal"

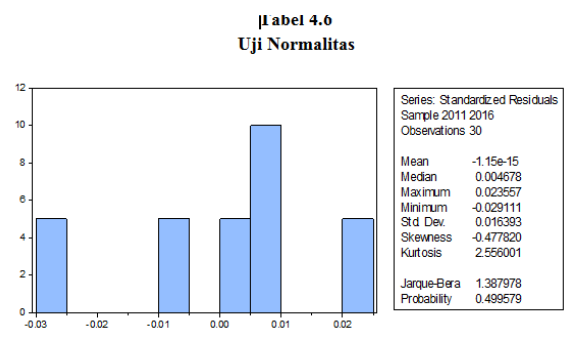

Dari hasil olah data diatas, pola grafik yang berdistribusi normal/ syarat normalitas dapat perpenuhi.Tentunya terllihat dari nilai Jarque Bera 1.387978 dan untuk nilai probabilitas 0.49957 . Yang artinya nilai tersebut $>\alpha$ 
$=0,05(5 \%),(0.499579>0,05) . \mathrm{D} c$

keterangan diatas dapat dinyatak:

bahwa model regresi bisa digunakan

karena sudah memenuhi unsur asumnormalitas.

\section{PengujianMultikolinieritas}

Pengujian ini dilakukan deng، tujuan mengetahui terdapatn! korelasi kuat hubungan linear ant variabel independen yaitu $\mathrm{CR}, \mathrm{DE}$ dan TATO.Model yang ba seharusnya tidak terjadi autokorela antar variabel independenny Karena bila terjadi autokorelasi akc menjadi tidak arthogonal.

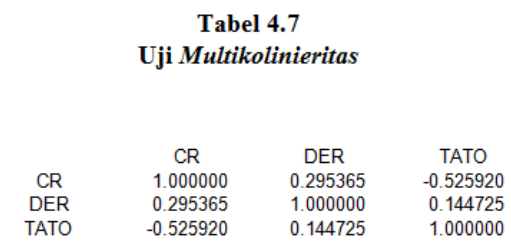

Pada tabel 4.5 diatas menunjukkan nilai untuk setiap variabel independen $\mathrm{CR}$ (X1) sebesar 1.000000, DER (X2) sebesar 0.295365, TATO (X3) sebesar 0.525920.Dimana masing-masir variabel independen, tidak terdap nilai koefisien korelasi yang leb besar dari 0,800 sehingga uji i menemukan tidak terjadin! multikolinieritas antara variabel independen

\section{Uji Heteroskedastisitas}

Uji ini dilakuakn dengan maksud untuk menguji apakah dalam model regresi linear terjadi ketidak samaan variance residual dari satu pengamatan ke dalam pengamatan lain. Jika variance residual dari satu pengamatan lain tetap maka disebut homokedastisitas. Dan apabila variance residual dari pengamatan satu ke yang lainnya berbeda, maka disebut heteroskedastisitas.

Tabel 4.8
Uji Heteroskedastisitas

\begin{tabular}{|c|c|c|c|c|}
\hline $\begin{array}{l}\text { F-6tatstic } \\
\text { Oos'R-6quared } \\
\text { Scaled explained SS }\end{array}$ & $\begin{array}{l}0.639939 \\
2.936287 \\
1.007058\end{array}$ & $\begin{array}{l}\text { Prob. F(3,2) } \\
\text { Prob. Cnl-Square } \\
\text { Prob. Cnl-Square }\end{array}$ & & $\begin{array}{l}0.6576 \\
0.4016 \\
0.7995\end{array}$ \\
\hline \multicolumn{5}{|c|}{$\begin{array}{l}\text { Test Equaton: } \\
\text { Dependent Variade: AFESID } \\
\text { Method. Least Squares } \\
\text { Date: O5:2817 Time: } 13.13 \\
\text { Sample: } 2011 \text { 2016 } \\
\text { Inciuded obsenvatons: } 6 \\
\end{array}$} \\
\hline Variade & Coenclent & Sta. Error & i-statstc & Prob. \\
\hline $\begin{array}{c}C \\
\text { CR } \\
\text { DER } \\
\text { TATO }\end{array}$ & $\begin{array}{r}-0.199674 \\
0.171902 \\
0.004703 \\
0.033356\end{array}$ & $\begin{array}{l}0.130745 \\
0.159902 \\
0.015590 \\
0.058514\end{array}$ & $\begin{array}{r}-1.104727 \\
1.079093 \\
0.3016055 \\
0.569090\end{array}$ & $\begin{array}{l}0.3844 \\
0.3934 \\
0.7914 \\
0.6257\end{array}$ \\
\hline $\begin{array}{l}\text { R-6quared } \\
\text { Adusted R-6quared } \\
\text { S.E. of regresslon } \\
\text { Sum squared resild } \\
\text { Log Feal hood } \\
\text { F-statstic } \\
\text { Prob(F-6tatstic) }\end{array}$ & $\begin{array}{r}0.059381 \\
-0.2765547 \\
0.012198 \\
0.000298 \\
21.22122 \\
0.639999 \\
0.657550\end{array}$ & $\begin{array}{l}\text { Mean dependent } \\
\text { S.D. dependent } \\
\text { Akake Into crilari } \\
\text { Schwarz crilerion } \\
\text { Hannan-Quinn on } \\
\text { Durbin-Watson st }\end{array}$ & & $\begin{array}{r}0.012753 \\
0.010796 \\
-5.740405 \\
-5.879232 \\
-6.295141 \\
2.913967\end{array}$ \\
\hline
\end{tabular}

Hasil pengolahan data diatas, heterokedasticity test glejser, dengan hasil probabilitas $O b s * R$ squared $=2.936287$, yang artinya > $\alpha=5 \% \quad(2.936287>\quad 0,05)$. Dari penjelasan diatas dapat ditarik 
kesimpulan tidak terjadi heterokedastisitas dari model regresi yang dilakukan.

\section{Uji Autokorelasi}

Uji ini dilakukan untuk mengetahui adanya korelasi antara penggangu pada periode saat ini ( $\mathrm{t})$ deng: pengganggu pada perior sebelumnya (t-1).Autokorela muncul karena observasi yar berurutan sepanjang waktu yar berkaitan dengan satu sama lain di timbul akibat residual tidak beb: dari satu observasi ke observa yang lain. Pada umumnya masalc autokorelasi dialami oleh data yar bersifat time series.Uji dilakuk: dengan uji Durbin Watson.

Tabel 4.10
Hasil Uji Autokorelasi - Durbin Watson

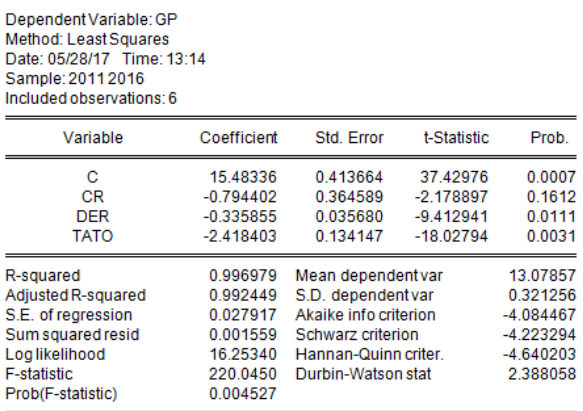

Dari uji autokorelasi deng: metode least squares didapat ha: $\mathrm{Ho}_{1}$ : Durbin-Watson stat sebesar 2.3880. yang mana nilai tersebut berar $\mathrm{Ha}_{1}$ diantara kriteria $(1.55-2.46)$ sehing: dengan ketentuan pada tabel pedoman interprestasi uji Durbin Watsonmaka model regresi ini dengan keterangan tanpa autokorelasi.

\section{B. HASIL ANALISA DATA}

\section{Uji Parsial (Uji t)}

Melalui uji-tini, dapat dijadikan sebagai parameter apakah sudah mampu untuk menjalankan perilaku variable bebas (independen) dalam mempengaruhi variable terikat (dependen).

Adapun kriteria signifikansi 5\% untuk menentukan berpengaruh signifikan atau tidaknya antara kedua variabel dengan melihat nilai prob. pada hasil olah data program E-views 7 sebagai berikut:

1) Jika prob. $t{ }_{\text {hitung }}<0,05$ : Ho tidak diterima dan $\mathrm{H}_{\mathrm{a}}$ diterima

2) Jika prob. $t_{\text {hitung }}>0,05$ : Ho diterima dan $\mathrm{H}_{\mathrm{a}}$ tidak diterima

\section{a) Pengaruh CR Terhadap Gross Profit}

Rumusan Hipotesis pada pengaruh CR terhadap Gross Profit adalah sebagai berikut:

CR tidak berpengaruh signifkan terhadap Gross Profit

CR berpengaruh signifikan terhadap Gross Profit 
Berdasarkan tabel 4.4, nil $\mathrm{Ha}_{3}$ : TATO berpengaruh signifikan signifikan yang dihasilkan adalı $(0.0000<0,05)$. Dengan demikic artinya $\mathrm{Ho}_{1}$ tidak diterima dan $\mathrm{H}$ diterima.

"CR berpengaruh signifikan terhada Gross Profit perusahaan"

b) Pengaruh DER Terhadap Gro, " Profit

Rumusan Hipotesis pada pengarı DER terhadap Gross Profit adalah sebagai berikut:

d) Pengaruh Gross Profit terhadap PER

$\mathrm{Ho}_{2}$ : DER tidak berpengaruh signifk terhadap Gross Profit

$\mathrm{Ha}_{2}$ : DER berpengaruh signifikan terhad: terhadap Gross Profit

Berdasarkan tabel 4.4, nilai signifikan yang dihasilkan adalah $(0.0000<0,05)$. Dengan demikian artinya $\mathrm{Ho}_{3}$ tidak diterima dan $\mathrm{Ha}_{3}$ diterima.

TATO berpengaruh signifikan terhadap Gross Profit perusahaan"

Rumusan Hipotesis pada pengaruh Gross Profit terhadap PER adalah sebagai berikut:

Gross Profit

$\mathrm{Ho}_{4}$ : Gross Profit tidak berpengaruh Berdasarkan tabel 4.4, nil signifkan terhadap PER perusahaan signifikan yang dihasilkan adalıHa: Gross Profit berpengaruh signifikan $(0.0000<0,05)$. Dengan demikic terhadap PER perusahaan artinya $\mathrm{Ho}_{2}$ tidak diterima dan $\mathrm{F}$ Berdasarkan tabel 4.5, nilai diterima.

"DER berpengaruh signifikan terhada Gross Profit perusahaan"

c) Pengaruh TATO Terhadap Gro Profit

“Gross signifikan yang dihasilkan adalah $(0.0000<0,05)$. Dengan demikian artinya $\mathrm{Ho}_{4}$ tidak diterima dan $\mathrm{Ha}_{4}$ diterima.

Rumusan Hipotesis pada pengarı TATO terhadap Gross Profit adalah

\section{Uji Secara Simultan (Uji F)} sebagai berikut:

$\mathrm{Ho}_{3}$ : TATO tidak berpengaruh signifk: terhadap Gross Profit

Uji F dilakukan dengan maksud mengetahui pengaruh masingmasing variabel secara simultan atau bersama-sama. 
Adapun kriteria signifikan 5\% untıM menentukan berpengaruh signifikc atau tidak berpengaruh segnifikc secara simultan antara variabel Independen terhadap variabel dependen adalah dengan melih nilai prob. pada hasil olah da program E-views 7 dengc ketentuan dibawah ini:

1) Apabila (prob) $\mathrm{f}_{\text {hitung }}<0,05: \mathrm{F}$ ditolak dan $\mathrm{H}_{\mathrm{a}}$ diterima

2) Apabila (prob) f hitung $>0,05: \mathrm{F}$ diterima dan $\mathrm{H}_{1}$ ditolak

a) Pengaruh CR, DER, TAT Secara Simultan Terhadap Gro.

\section{Profit}

Rumusan Hipotesis pada pengarı CR, DER dan TATO seca simultan terhadap Gross Proj adalah sebagai berikut:

Ho5: CR, DER dan TATO dengan bersam sama tidak mempengaru signifikan Gross Profit perusahaan

Ha5: CR, DER dan TATO secara simultan berpengaruh signifikan terhadap Gross Profit perusahaan

Berdasarkan tabel 4.4, mal diperoleh (prob) $f_{\text {hitung }}<0,05$ atc $(0,0000<0,05)$. Dari has penjelasan diatas artinya $\mathrm{Ho}_{5}$ tidi diterima dan $\mathrm{Ha}_{5}$ diterima.
"CR, DER, TATO bersama-sama berpengaruh signifikan terhadap Gross Profit perusahaan"

b) Pengaruh Gross Profit Secara Simultan Terhadap PER

Rumusan Hipotesis pada pengaruh Gross Profit secara simultan terhadap PER perusahaan adalah sebagai berikut:

Ho$_{6}$ : Gross Profit secara simultan tidak berpengaruh signifikan terhadapPER perusahaan

Ha6: Gross Profit secara simultan berpengaruh signifikan terhadapPER perusahaan

Berdasarkan tabel 4.5, maka diperoleh (prob) $\mathrm{f}_{\text {hitung }}<0,05$ atau $(0,0000<0,05)$. Dari hasil penjelasan diatas artinya $\mathrm{Ho}_{6}$ tidak diterima dan $\mathrm{Ha}_{6}$ diterima.

“Gross Profit secara simultan berpengaruh signifikan terhadap Gross Profit perusahaan".

3. Pengujian Koefisien Determinasi dan Persamaan Regresi

a) Pengujian Koefisien Determinasi

Pengujian ini dilakukan untuk mengetahui besarnya pengaruh antara masing-masing variabel secara bersama-sama dalam satuan persen.Koefisien yang digunakan 
bertujuan untuk mengukur besarn! persentase yang digunakan unt mampu mejelaskan masing-masir variabel.

Dari hasil olah data tabel 4.4 diperoleh nilaiAdjusted $R$-Square (R2) dengan hasil 0.996018.Dapat disimpulkan bahwa pengaruh kedua variabel sebesar $99.60 \%$. Dan sisanya 11.40 dipengaruhi faktor lain yang tidak diteliti variabelnya didalam penelitian ini.

Dengan demikian menurut kriteria dari Johanes Supranto (2002: 122), "nilai 0.99 berada pada rentang $(0.80$ - 1.00) yang menunjukan hubungan variabel bebas terhadap variabel terikat sangatlah kuat".

b) Persamaan Model Regresi CR, DER, TATO Terhadap Gross Profit

Penelitian dengan menggunakan model regresi data panel ini bertujuan untuk mengetahui pengaruh antara variabel bebas $d \varepsilon$ terikat, hubungan fluktuatif variab $\mathbf{V}$. dan faktor fundamental yang dap diformulasikan dan salir mempengaruhi. Berdasarkan has E-views 7 ditabel 4.10 diata diperoleh persamaan model regresi antara variable CR, DER, TATO terhadap Gross Profit sebagi berikut:

$\log \mathrm{Y}=15.48336-0.794402 \mathrm{CR}-0.335855 \mathrm{DER}-2.418403 \mathrm{TATO}$

Dengan rujukan persamaan diatas, bisa dianalisa dengan beberapa pertimbangan dibawah:

a) Konstanta regresi CR -0.794402 dapat disimpulkan apabila ada penambahan $\mathrm{CR}$ senilai 1, dapat menurunkan Gross Profit sebesar 0.794402

b) Konstanta regresi DER sebesar 0.335855 menyatakan bahwa setiap penambahan DER sebesar 1 maka akan menurunkan nilai Gross Profit sebesar -0.335855 .

c) Konstanta regresi TATO sebesar 2.418403 dapat disimpukan setiap penambahan TATO senilai $1 \%$ dapat menurunkan Gross Profit senilai -2.418403 .

\section{KESIMPULAN DAN SARAN}

\section{A. Kesimpulan}

1. Pengaruh CR, DER, TATO secara parsial terhadap Gross Profit perusahaan adalah: 
a)CR berpengaruh signifikan terhadap Gross Profit perusahaan.

b)DER berpengaruh signifikan terhadap Gross Profit perusahaan.

c) TATO berpengaruh signifikan terhadap Gross Profit perusahaan.

2. Pengaruh CR, DER, TATO secara simultan terhadap Gross Profit perusahaan adalah:

a) CR, DER, TATO secara simultan berpengaruh signifikan terhadap Gross Profit perusahaan.

b) Pengaruh Gross Profit terhadap PER perusahaan adalah:

Gross Profit berpengaruh signifikan terhadap PER perusahaan.

\section{B. Saran}

1. Dari hasil penelitian diatas bahwa, gross profit berpengaruh signifikan terhadap nilai perusahaan. Dengan demikian perusahaan harus mampu terus meningkatkan laba perusahaan demi kemajuan dan kelangsungan hidup perusahaan yang lebih baik lagi.

2. CR, DER dan TATO seuaıa simultan dalam penelitian ini menunjukkan pengaruh yang signifikan terhadap Gross Profit (GP) perusahaan, dengan demikian perusahaan harus mampu mengelola dan mengendalikan seluruh nilai CR, DER dan TATO untuk dapat meningkatkan gross profit perusahaan secara maksimal dan lebih efektif lagi.

3. Dari hasil penelitian untuk variabel Gross Profit ( GP ) secara simultan juga berpengaruh signifikan terhadapnilai perusahan( PER ). Sehingga perusahaan harus mampu terus meningkatkan nilai Gross Profit sebagai nilai jual bagi para investor untuk dapat menanamkan modalnya diperusahaan yang kita kelola.

4. Penelitian yang dilakukan dan juga sebagai rujukan data adalah data keuangan perusahaan Sub Sektor Kimia tahun 2011 sampai dengan tahun 2016, sehingga untuk tahuntahun sebelumnya atau tahun-tahun mendatang, hasil penelitian ini masih perlu diuji validasinya.

\section{DAFTAR PUSTAKA}

Ade Irawan. 2011. Analisis Pengaruh Return On Assets (ROA), Loan To Deposit Ratio (LDR), dan Non Performing Loan (NPL) 
Jurnal Semarak,Vol. 2,No.1, Februari 2019, Hal (44- 63)

@Prodi Manajemen Fakultas Ekonomi Universitas Pamulang

Terhadap Price Earning Ratio Chairul Maron. 2001. Pedoman (PER) Serta Dampaknya Penyajian Laporan Keuangan.

Terhadap Return Saham Pada Jakarta: Grasindo

Bank Umum Yang Terdaftar Di Darsono, dan AShari. 2005. Pedomam

Bursa Efek Indonesia Periode

Praktis Memahahi Laporan

Tahun 2011-2014. Tesis.Jakarta:

Keuangan Edisi Pertama.

Magister Manajemen Universitas

Yogyakarta: ANDI.

Pamulang.

David Tjondro,R. Wilopo. 2011.

Agus sartono.2001. Manajemen Pengaruh Good Corporate

Keuangan Teori dan Aplikasi.

Governance

(Gcg)

Edisi Keempat Cetakan Kedua.

TerhadapProfitabilitas

Dan

Yogyakarta: BPFE

Kinerja Saham Perusahaan

Atmaja, Lukas Setia. 2003. PerbankanYang Tercatat Di

Manajement Keuangan (Edisi

Bursa Efek Indonesia.Journal of

Revisi). Edisi Ketiga.

Business and Banking Volume 1,

Yogyakarta: ANDI

No. 1.

Bambang Riyanto. 2001. Dasar-dasar

Djarwanto 2001.Pokok-pokok Analisis

Pembelanjaan Perusahaan.

Laporan Keuangan.. Yogyakarta:

Yogyakarta: BPFE

BPFE

Basri. 2000. Manajemen Keuangan.

Edisi Ketiga. Yogyakarta: BPFE

analisis pengaruh good

corporate governance dan

rencana strategis terhadap 
JURNAL ILMIAH

candenan

vallevied

peningkatan kinerja pada unit

internal audit \& control PT.

GMF aero Asia. Tesis.universitas

pamulang.

Ellen dan Juniarti. 2013. Penerapan

Good Corporate Governance,

Dampaknya Terhadap Prediksi

Financial Distress Pada Sektor

Aneka Industri Dan

Barang Konsumsi.Jurnal.Business

Accounting Review. VOL.1, NO.

2, 2013 1. Akuntansi Bisnis.

Universitas Kristen Petra

Enny Pudjiastuti dan Suad Husnan.

2002. Dasar-dasar Manajemen

Keuangan. Yogyakarta: UUP

AMP YK PN

Ferry Madi Ika Pratama. 2013.

Pengaruh Return On Assets,

Leverage,

Corporate

Governance, Ukuran Perusahaan

Dan Kompensasi Rugi Fiskal

Pada Tax Avoidance. ISSN 1410-
4628 58Buletin Studi Ekonomi.

Fakultas Ekonomi, UPN Veteran

Jawa Timur, Surabaya.Volume

18, No. 1, 2013

Jumingan. 2006. Analisis Laporan

Keuangan. Edisi Pertama.

Jakarta: PT Bumi Aksara

Kasmir.2008. Analisi Laporan keuangan. Jakarta: Rajawali Pers

Kasmir. 2008. Anallisis Laporan Keuangan. Jakarta: PT. Raja Grafindo Persada.

Kasmir. 2010. Pengantar Manajemen

Keuangan. Edisi Pertama Cetakan Kedua. Jakarta: Kencana Prenada Media Group

Lukas Setia Atmaja. 2008. Teori dan Praktik Manajemen Keuangan. Yogykarta: Andi Mahmud Hanafi. 2001. Analisis 